\title{
HAV in fresh vegetables: a hidden health risk in district Mardan, Pakistan
}

\author{
Waleed Khan', Muhammad Irshad', Gauhar Rehman² and Anwar Hussain ${ }^{1 *}$
}

\begin{abstract}
Hepatitis $A$ is an acute inflammation of the liver caused by the hepatitis A virus (HAV) in human. The path of entry of HAV to the bloodstream is the epithelium of the intestine. Liver inflammation occurs when HAV multiplies within the hepatocytes and Kupffer cells of the liver. HAV is mostly transmitted by contaminated water, fruits and vegetables. The purpose of the current study was to evaluate fresh vegetables raised on the fecal contaminated water for the detection of HAV by PCR method. Twenty nine samples were collected from 13 different locations of district Mardan and screened for the presence of HAV. Village Bajowro near Takht Bhai was the most contaminated site having HAV in all vegetables grown over there. Water samples collected from this area proved to be contaminated with HAV. It may be concluded that fecal contaminated water is unsafe for irrigation because of the health risk associated with such practices.
\end{abstract}

Keywords: Hepatitis A virus; Domestic sewage; Vegetables; PCR

\section{Introduction}

Viruses are the most familiar causes of food-borne infections in human population. They remain inert in or on contaminated food items which may transmit infection. Besides several groups of viruses responsible for the contamination of food items, HAV and gastroenteritis viruses are the major food-borne viral pathogens which infect via the gastrointestinal tract (Vaughan et al. 2013; Lee et al. 2013). Viruses responsible for infection via the gastrointestinal tract are expelled in vomit and may likewise be excreted in feces. Viral pathogen may contaminate foods either directly from infected people or through sewage pollution (Seymour and Appleton 2001). Untreated or inadequately treated sewage is one of the key factors contaminating food and water (Iritani et al. 2014). Fruits and vegetables that are consumed without cooking are particularly risky in spreading viral pathogens.

HAV may make its way to vegetables from sewage containing human feces (Bosch 1998; Rodríguez-Lázaro et al. 2012). HAV effectively resists detergents, acids (even $\mathrm{pH} \mathrm{1}$ ), solvents and extreme temperatures (up to $60^{\circ} \mathrm{C}$ ) (Wright 2013; Cappellozza et al. 2012). These characters

\footnotetext{
* Correspondence: drhussain@awkum.edu.pk

'Department of Botany, Shankar Campus, Abdul Wali Khan Univerity, Mardan 23200, Khyber Pakhtunkhwa, Pakistan

Full list of author information is available at the end of the article
}

make it suitable for survival in sewage of domestic origin. Its survival time may reach up to months even years in fresh and salt water (Sobsey et al. 1986).

Mardan is the second largest city of Khyber Pakhtunkhwa Pakistan, which occupies an area of $1,632 \mathrm{~km}^{2}$, located at $34^{\circ} 12^{\prime} 0 \mathrm{~N} \mathrm{72} 2^{\circ} 1^{\prime} 60 \mathrm{E}$ and an altitude of 283 metres (928 ft) (Khan et al. 2011). A project of sewage treatment plant (STP) with total cost of Rs. 51.89 million was started by the Mardan Development Authority with the collaboration of Asian Development Bank in 1980. The project was completed and its control was handed over to Tehsil Municipal Administration (TMA) on July 14, 1999 to manage its functioning (Dawn News 2012: Mardan sewage treatment project rendered useless From the Newspaper Updated Apr 18, 2012 12:08 am). However, the project never worked and the dream of cleaner Mardan did not come true. For the same reason, practice of dumping sewage is directly into canals and other freshwater bodies without any pre-treatment is continued. Water in the canals are predominantly contaminated with sewage which is used to irrigate agriculture fields. Situation become verse in areas where domestic sewage is directly used for the purpose or irrigation. Purpose of the current study was to investigate the presence of HAV in fresh vegetables grown on the field irrigated with fecal contaminated water in the target area.

\section{空 Springer}




\section{Material and methods}

Different locations of district Mardan where agriculture fields are irrigated directly with domestic sewage or with the canals contaminated by domestic sewage, were selected for sampling. Sampling sites are shown on the map of district Mardan, Pakistan (Figure 1). Vegetables growing at the time of sampling (March-September, 2011) were collected and quickly frozen in liquid nitrogen. In lab, RNA extraction was accomplished by using Gene JET plant RNA purification kit (Fermentas, Germany) by following the manufacturer's instructions. Seedlings fed with HAV positive serum, were used as positive control. Water samples were also processed for the extraction of viral RNA by using PowerWater ${ }^{\bullet}$ RNA Isolation Kit (Carlsbad, CA USA). RNA was extracted from serum by using Favor prep viral nucleic acid extraction kit (Farvogen, Germany), according to its manufacturer's protocol. Thirty $\mu \mathrm{L}$ of RNA samples were taken in properly labelled micro-centrifuge tubes. To the RNA samples, $30 \mu \mathrm{L}$ of PCR Master Mix and 1.25 $\mu \mathrm{L}$ Reverse

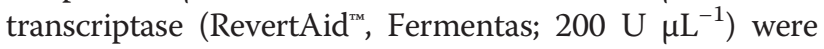
also added. To this mixture, 100 pmol of antisense primer (Table 1) were added in each centrifuge tube and incubated at $42^{\circ} \mathrm{C}$ for $50 \mathrm{~min}$ (Croci et al. 2002). The reaction was stopped by incubating the reaction mixture at $95^{\circ} \mathrm{C}$ for $3 \mathrm{~min}$. Thirty $\mu \mathrm{L}$ PCR Master Mix, 2.5 $\mu \mathrm{L}$ Taq polymerase $(2.5 \mathrm{U})$ and $2.25 \mu \mathrm{L}$ of sense primer (100 pmol) were added to RT-PCR product. The final volume of the reaction mixture was adjusted to $90 \mu \mathrm{L}$ with nuclease free water. The cDNA was amplified via PCR under conditions described earlier (Croci et al. 2002). Twenty $\mu \mathrm{L}$ of each
PCR product was mixed with $3 \mu \mathrm{L}$ of $6 \mathrm{X}$ bromophenol blue (Fermentas) and were resolved on 1\% agarose gel in a running buffer containing $0.2 \mu \mathrm{g} / \mathrm{mL}$ ethidium bromide. To determine size of amplified DNA fragments on the agarose gel, $3 \mu \mathrm{L}$ of $100 \mathrm{bp}$ DNA ladder (Fermentas) was used. Gel documentation system (BioDoc/It. 220 imaging system, S/N 51410-006, Cambridge, UK) was used to observe PCR products on the gel and to capture its image.

\section{Results}

During our survey, we found that domestic sewage was running directly to canals irrigating different areas of Mardan. In some places, such as Bajawro kalay and Guli Bagh, fields were irrigated directly with domestic sewage containing human feces. The areas were also best for raising vegetables among different locations of district Mardan. According to the local community, different vegetables including tomato, peppermint, coriander, radish, turnip, cabbage, potato, okra, chili, apple gourd and bottle gourd etc.

The sampling sites were selected on the basis of fertility of the agriculture fields mainly cultivated with vegetables and bad quality of water used for irrigation purpose. Different vegetables were sampled from thirteen different locations of Mardan. Amplification of 416 bp DNA fragment with HAV specific primers served to reveal the presence of HAV in the extract of the vegetable under question. A clear band of the mentioned size in the positive control (extract from vegetables fed with HAV positive serum) validated the procedure of RNA isolation and PCR conditions. Location-wise list of vegetables along

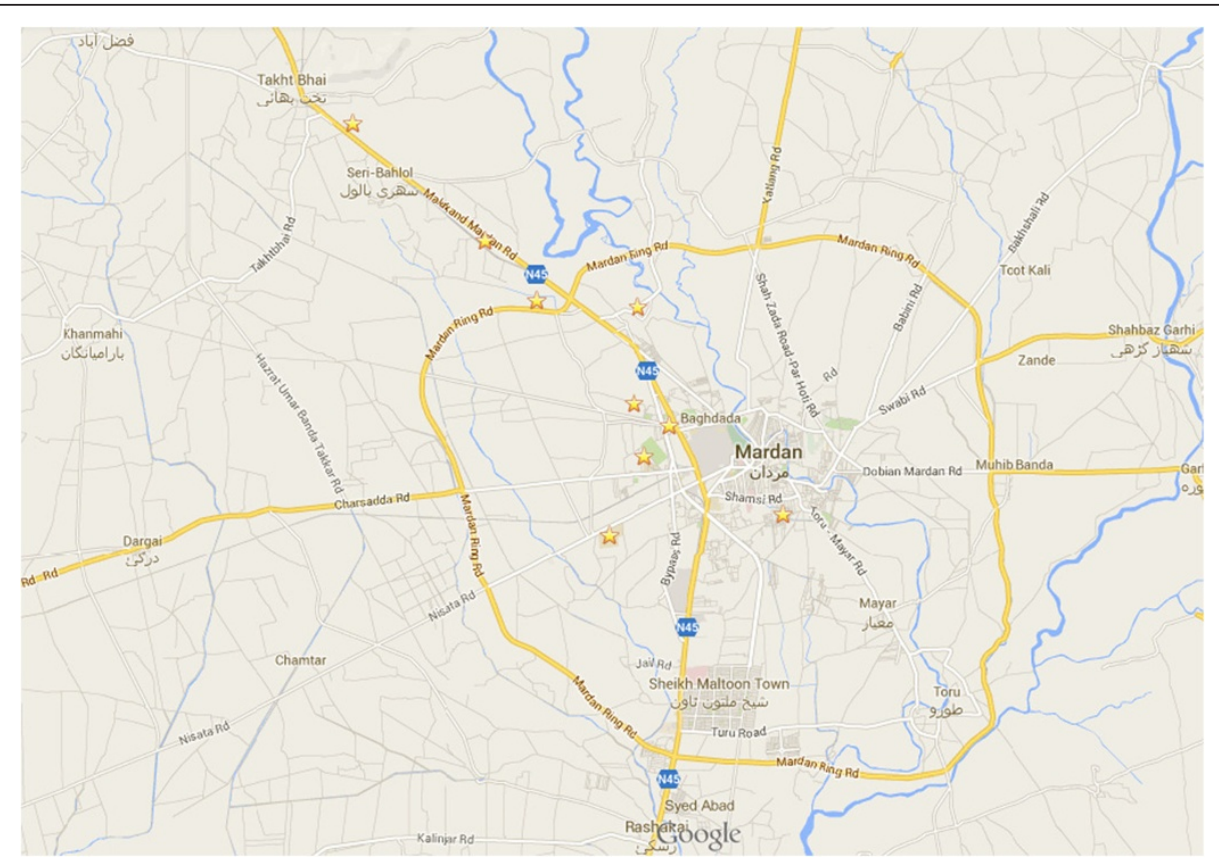

Figure 1 Sampling sites are shown (starred) on the map of District Mardan Khyber Pakhtunkhwa, Pakistan. 
Table 1 Sequence of sense and antisense primers used in PCR and RT-PCR

\begin{tabular}{llll}
\hline S.No & Primers & Sequences & Reference \\
\hline 1. & Antisense primer & 5'-CAGGGGCATTTAGGTTT-3' & Croci et al. 2002 \\
2. & Sense primer & 5'-CATATGTATGGTATCTC & \\
& & AACAA-3' & \\
\hline
\end{tabular}

with results indicating the presence or absence of HAV in these vegetables is given in Table 2. The area of Sazuddin is located of Mardan city. By the time we visited the area for sampling, Brassica oleraceae, Solanum lycopersicum and Luffa acutangula were grown. Most of the vegetables were quiet healthy and fresh with no visible sign or symptoms of disease. No HAV threat could be confirmed by

\begin{tabular}{|c|c|c|c|}
\hline S.No. & Vegetables & Location & HAV \\
\hline 1 & Cauliflower & \multirow{3}{*}{$\begin{array}{l}\text { L1. Sazodin near Rehman cotton mill } \\
\text { Takht Bhai. }\end{array}$} & \multirow[t]{3}{*}{-} \\
\hline 2 & Tomato & & \\
\hline 3 & Ridge gourd & & \\
\hline 4 & Brinjal & \multirow[t]{3}{*}{ L2. Samar Bagh Takht Bhai } & \multirow[t]{3}{*}{-} \\
\hline 5 & Ridge gourd & & \\
\hline 6 & Pumpkin & & \\
\hline 7 & Ridge gourd & \multirow{3}{*}{$\begin{array}{l}\text { L3. Bajawro kalay near Tablighi Markaz } \\
\text { Takht Bhai }\end{array}$} & \multirow[t]{3}{*}{+} \\
\hline 8 & Pumpkin & & \\
\hline 9 & Mint & & \\
\hline 10 & Bitter gourd & \multirow[t]{2}{*}{ L4. Chail, Takht Bhai } & \multirow[t]{2}{*}{-} \\
\hline 11 & Pumpkin & & \\
\hline 12 & Bitter gourd & \multirow{2}{*}{$\begin{array}{l}\text { L5: Western Bypass near Research } \\
\text { Form Malakand road Mardan }\end{array}$} & \multirow[t]{2}{*}{-} \\
\hline 13 & Pumpkin & & \\
\hline 14 & Pumpkin & \multirow{2}{*}{$\begin{array}{l}\text { L6: Sharmakhano bridge and Lodhi } \\
\text { Abad Gujargharai, Mardan }\end{array}$} & \multirow[t]{2}{*}{-} \\
\hline 15 & Ridge gourd & & \\
\hline 16 & Ridge gourd & \multirow{2}{*}{$\begin{array}{l}\text { L7: Deuband colony Bypass road } \\
\text { Muqam, Mardan }\end{array}$} & \multirow[t]{2}{*}{-} \\
\hline 17 & Okra & & \\
\hline 18 & Pumpkin & \multirow{2}{*}{$\begin{array}{l}\text { L8: Miangul kalay near, Bypass road, } \\
\text { Mardan }\end{array}$} & \multirow[t]{2}{*}{-} \\
\hline 19 & Pepper & & \\
\hline 20 & Pepper & \multirow[t]{3}{*}{ L9: Bachakalay, Mardan } & \multirow[t]{3}{*}{-} \\
\hline 21 & Pumpkin & & \\
\hline 22 & Brinjal & & \\
\hline 23 & Ridge gourd & \multirow[t]{2}{*}{ L10: Guli Bagh, Mardan } & \multirow[t]{2}{*}{-} \\
\hline 24 & Okra & & \\
\hline 25 & Ridge gourd & \multirow{2}{*}{$\begin{array}{l}\text { L11: Meervas kalay Charsadda road } \\
\text { Mardan }\end{array}$} & \multirow[t]{2}{*}{-} \\
\hline 26 & Pumpkin & & \\
\hline 27 & Ridge gourd & \multirow{2}{*}{$\begin{array}{l}\text { L12: Tauheed colony near Charsadda } \\
\text { chowk, Mardan }\end{array}$} & \multirow[t]{2}{*}{-} \\
\hline 28 & Okra & & \\
\hline 29 & Cucumber & L13: Near Fazli Haq College Mardan & - \\
\hline
\end{tabular}

the current study, evidencing that vegetables grown in the area might be safe for human consumption.

Contaminated water drains and field of Samar Bagh irrigated with feces loaded water supported the growth of fresh and healthy vegetables, Solanum melongeana, L. acutangula and Cucurbeta pepo. PCR results proved that the vegetables of the area were free of HAV and hence, may be recommended for human consumption.

Dumping of domestic sewage into drains and ultimately to the canal was documented in Bajawro kalay near Tableghi Markaz, Takht Bhai. This area was the most polluted among the sampling sites. At the time of sampling, L. acutangula, C. pepo and Mentha piperita were collected from the fields. A band (416 bp) was detected on agarose gel in all the vegetables collected from the site (Figure 2), evidencing the presence of HAV. Additionally, HAV was also present in water sampled from this area.

Momordica charantia and C. pepo were collected from fields of Chail, Takht Bhai. No band of DNA was detected in the PCR products using RNA extract from these vegetables, confirming the absence of HAV. Hence, the vegetables may be safe for human consumption.

People of Western bypass near Tobacco Research station, Malakand road Mardan are mostly illiterate, involved in agriculture by profession and green vegetables are grown all over the area. We sampled $M$. charantia and C. pepo from the area. The vegetables were free of HAV contamination as confirmed by the absence of PCR product on the gel.

C. pepo and L. acutangula, sampled from the fields in Sharmakhanon Bridge, Gujar Garhai. These vegetables were free from HAV and may be acceptable for human consumption. Similarly, L. acutangula and Abelmoschus esculentus grown in Deuband Muqam bypass road, Mardan were also free of HAV. No HAV RNA was detected in C. pepo and Capsicum annuum of Miangulkalay bypass barafkhana, Mardan.

Canal flowing through Bacha kalay, Mardan, located at a distance of $2.5 \mathrm{Km}$ from Mardan city was also heavily polluted by human feces. However, vegetables grown in the area, C. annuum, Cucurbeta pepo and S. melongeana, were free of viral (HAV) contamination.

Guli bagh is an area located in the main city in close proximity to District Headquarter Hospital, Mardan. Canal passing through this area is heavily polluted with domestic sewage and hospital waste. Domestic sewage is also directly used for irrigating fields on which a number of different vegetables are grown. A. esculentus and $L$. acutangula were collected from this contaminated area. No HAV was confirmed by PCR.

The site of Sabzi Mandi Mirwas, Mardan, located at a distance of $1 \mathrm{Km}$ from Mardan city, is moderately populated with 40 houses of the local population. Cucurbeta 


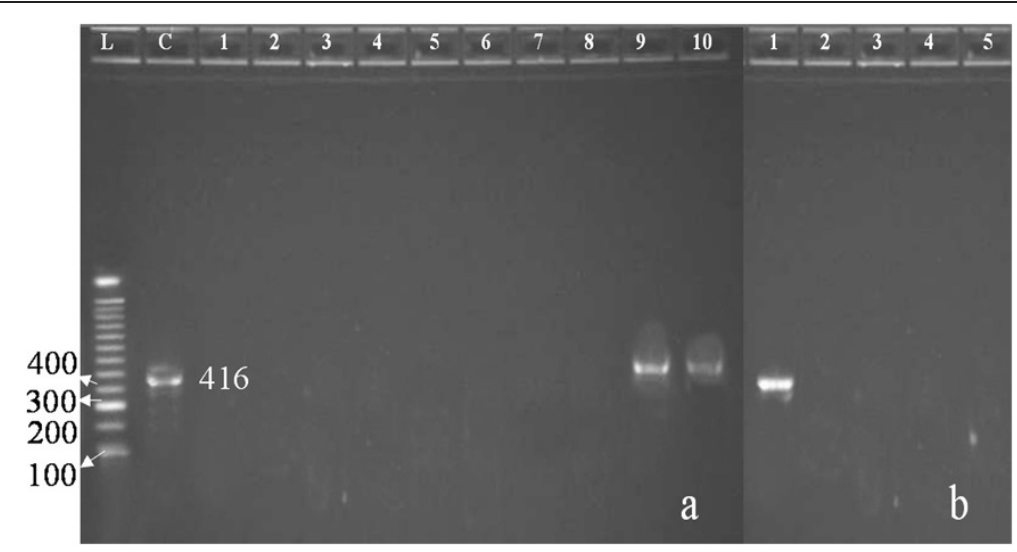

Figure 2 Single PCR product (416 bp) in wells labelled as c (control), 9a (L. acutangula), 10a (C. pepo) and 1b (M. piperita), evidencing the presence of HAV in vegetables sampled from Bajowro kale near Takht Bhai. Agarose gel shows RT-PCR results of different vegetable samples. No PCR product was detected in vegetables collected from Location 1 (1a, Cauliflower; 2a, tomato; 3a, Ridge-gourd ), Location 2 (4a, Brinjal; 5a, Ridge-gourd; 6a, Pumpkin), Location 4 (7a, Bittergourd; 8a, Pumpkin), Locaton 5 (2b, Bittergourd; 3b, Pumpkin), and Location 6 (4b, Pumpkin; 5b, Ridge-gourd).

pepo and L. acutangula were collected from this area. No band corresponding to HAV RNA was detected on the gel indicating that the vegetables collected from this area were free from HAV contamination.

HAV contamination was not detected in the vegetables collected from Tauheed colony, Charsadda road, Mardan, which is located at a distance of $2 \mathrm{Km}$ from Mardan city and are near Fazli Haq College, Mardan, about $3 \mathrm{Km}$ from main city.

\section{Discussion}

Vegetables from the most polluted area of district Mardan, where irrigation with fecal contaminated water is a common practice, were analyzed for HAV, a food born pathogen. Out of thirteen different locations, HAV was detected in the vegetables grown in Bajowro kalay only. We used RT-PCR based detection method for HAV detection. The method was previously used with success to determine the absorption of mammalian virus by vegetables (Seymour and Appleton 2001). Molecular biology techniques have been proposed for the sensitive and specific detection of some enteric viruses (Jean et al. 2001). The presence of HAV in three vegetables (C. pepo, M. piperita and L. acutangula) sampled from the area may be regarded as a hidden health risk to human population consuming such contaminated vegetables. The result of this study supported the idea that irrigation with fecal contaminated water may lead to HAV contamination of the crop. There are reports about the importance of HAV as a waterborne pathogen and the phenomenon is well recognized (Deboosere et al. 2012; Miura et al. 2013; Schultz and Myrmel 2013). Among the vegetables contaminated with HAV, $M$. peperita is consumed in its raw form and hence, may be a greater risk. Based on this postulation, other vegetables grown in such areas and consumed in raw form can be equally hazardous for humans. The initial survey has indicated the cultivation of tomato cucumber, onion, coriander, radish, carrot etc. on these fields which may magnify the intensity of the associated risk because of their consumption in raw form. Additionally, the HAV contaminated vegetables which are consumed in cooked form, may also contribute to the risk by communicating the virus to the HAV free vegetables and fruits consumed in raw form, through the use common kitchen utensils. Several HAV outbreaks due to consumption of berries and vegetables have been reported previously (Butot et al. 2007). Reports on contamination of vegetables from several parts of the world (Mukomolov et al. 2012; Hernández et al. 1997; Felix-Valenzuela et al. 2012) indicate the gravity of the situation.

It may be concluded that crop irrigated with sewage water may be screened not only for HAV, but also for other mammalian viruses, especially human pathogens of viral, bacterial, fungal and other origin. Based upon this study, the human consumption of vegetables grown on fields irrigated with fecal contaminated water is not recommended. Such ill practices need prompt attention of the government and civil society. Society mobilization against such practices is highly desired and the purpose may be achieved by educating people to understand this hidden health risk.

\section{Competing interests}

The authors declare that there is no conflict of interest.

\section{Authors' contribution}

$\mathrm{AH}$ conceived the idea and supervised the experimental work. WK collected samples and participated in writing draft of the manuscript. MI and GR isolated RNA, did PCR and run samples on gel. Final editing of the MS was done by $\mathrm{AH}, \mathrm{MI}$ and $\mathrm{GR}$. All authors read and approved the final manuscript. 


\section{Author details}

'Department of Botany, Shankar Campus, Abdul Wali Khan Univerity, Mardan 23200, Khyber Pakhtunkhwa, Pakistan. ²Department of Zoology, Shankar Campus, Abdul Wali Khan Univerity, Mardan 23200, Khyber Pakhtunkhwa, Pakistan.

Received: 30 September 2014 Accepted: 6 November 2014

Published: 18 November 2014

\section{References}

Bosch A (1998) Human enteric viruses in the water environment: a minireview. Int Microbiol 1(3):191-196

Butot S, Putallaz T, Sanchez G (2007) Procedure for rapid concentration and detection of enteric viruses from berries and vegetables. Appl Environ Microbiol 73(1):186-192

Cappellozza E, Arcangeli G, Rosteghin M, Kapllan S, Magnabosco C, Bertoli E, Terregino C (2012) Survival of hepatitis A virus in pasteurized milk clams. Italian J Food Sci 24(3):

Croci L, De Medici D, Scalfaro C, Fiore A, Toti L (2002) The survival of hepatitis A virus in fresh produce. Int J Food Microbiol 73(1):29-34

Deboosere N, Pinon A, Caudrelier Y, Delobel A, Merle G, Perelle S, Temmam S, Loutreul J, Morin T, Estienney M (2012) Adhesion of human pathogenic enteric viruses and surrogate viruses to inert and vegetal food surfaces. Food Microbiol 32(1):48-56

Felix-Valenzuela L, Resendiz-Sandoval M, Burgara-Estrella A, Hernández J, MataHaro V (2012) Quantitative detection of hepatitis a, rotavirus and genogroup I norovirus by RT-qPCR in fresh produce from packinghouse facilities. J Food Saf 32(4):467-473

Hernández F, Monge R, Jiménez C, Taylor L (1997) Rotavirus and hepatitis A virus in market lettuce (Latuca sativa) in Costa Rica. Int J Food Microbiol 37(2):221-223

Iritani N, Kaida A, Abe N, Kubo H, Sekiguchi J-I, Yamamoto SP, Goto K, Tanaka T, Noda M (2014) Detection and genetic characterization of human enteric viruses in oyster-associated gastroenteritis outbreaks between 2001 and 2012 in Osaka City, Japan. J Med Virol

Jean J, Blais B, Darveau A, Fliss II (2001) Detection of hepatitis A virus by the nucleic acid sequence-based amplification technique and comparison with reverse transcription-PCR. Appl Environ Microbiol 67(12):5593-5600

Khan M, Hussain F, Musharaf S (2011) A fraction of fresh water algae of kalpani stream and adjoining area of district mardan, Pakistan. Int J Biosci 1(3):45-50

Lee RM, Lessler J, Lee RA, Rudolph KE, Reich NG, Perl TM, Cummings DAT (2013) Incubation periods of viral gastroenteritis: a systematic review. BMC Infect Dis 13(1):446

Miura T, Parnaudeau S, Grodzki M, Okabe S, Atmar RL, Le Guyader FS (2013) Environmental detection of genogroup I, II, and IV noroviruses by using a generic real-time reverse transcription-PCR assay. Appl Environ Microbiol 79(21):6585-6592

Mukomolov S, Kontio M, Zheleznova N, Jokinen S, Sinayskaya E, Stalevskaya A, Davidkin I (2012) Increased circulation of hepatitis A virus genotype IIIA over the last decade in St Petersburg, Russia. J Med Virol 84(10):1528-1534

Rodríguez-Lázaro D, Cook N, Ruggeri FM, Sellwood J, Nasser A, Nascimento MS D'Agostino M, Santos R, Saiz JC, Hernández A (2012) Virus hazards from food, water and other contaminated environments. FEMS Microbiol Rev 36(4):786-814

Schultz AC, Myrmel M (eds) (2013) Methods for detection of viruses in food (Norovirus and hepatitis A virus), vol 6. Food Borne Viruses and Prions and Their Significance for Public Health. Wageningen Academic Pub,

Seymour IJ, Appleton H (2001) Foodborne viruses and fresh produce. J Appl Microbiol 91(5):759-773

Sobsey MD, Shields PA, Hauchman FH, Hazard RL, Caton lii LW (1986) Surviva and transport of hepatitis A virus in soils, groundwater and wastewater. Water Sci Technol 18(10):97-106

Vaughan G, Xia G, Forbi JC, Purdy MA, Rossi LMGA, Spradling PR, Khudyakov YE (2013) Genetic relatedness among hepatitis A virus strains associated with food-borne outbreaks. PLoS One 8(11):e74546

Wright WF (2013) VII. Approach to Hepatic Infections. Essentials of Clinical Infectious Diseases. Demos Medical Publishing,

doi:10.1186/2193-1801-3-675

Cite this article as: Khan et al:: HAV in fresh vegetables: a hidden health risk in district Mardan, Pakistan. SpringerPlus 2014 3:675

\section{Submit your manuscript to a SpringerOpen ${ }^{\circ}$ journal and benefit from:}

- Convenient online submission

- Rigorous peer review

- Immediate publication on acceptance

- Open access: articles freely available online

- High visibility within the field

- Retaining the copyright to your article

Submit your next manuscript at $>$ springeropen.com 